\title{
SUBLETHAL TOXICITY OF A DELTAMETHRIN-BASED INSECTICIDE IN RAINBOW TROUT, ONCORHYNCHUS MYKISS (WALBAUM, 1792) EMPHASIZING ON THYROID HORMONE RECEPTORS
}

\author{
MERIÇ TURGUT, İ. \\ Ankara University, Faculty of Agriculture, Department of Fisheries and Aquaculture \\ Engineering, TR-06110 Dışkapı, Ankara, Turkey \\ (phone: +90-312-5961505; fax: +90-312-3185298) \\ *Corresponding author \\ e-mail:meric@agri.ankara.edu.tr \\ (Received 16 $6^{\text {th }}$ Jun 2017; accepted $3^{\text {rd }}$ Oct 2017)
}

\begin{abstract}
Metrodesis, a deltamethrin containing commercial formulation has been extensively used in Turkey, in the framework of integral pest management thanks to its target-specific toxicity. So as to assess the potential impacts of Metrodesis (EC; active ingredient $25 \mathrm{~g} / \mathrm{L}$ of deltamethrin) on thyroid hormone (TH) homeostasis of rainbow trout (Oncorhynchus mykiss); mRNA levels of thyroid hormone receptors (TRs), TR $\alpha$ and $T R \beta$, were determined by RT-PCR soon after sublethal administration in a static bio-assay system. The sublethal dose of $4.15 \mu \mathrm{g} / \mathrm{L}\left(1 / 4\right.$ of $\mathrm{LC}_{50}$ value) led to induction of relative expression levels of $T R \alpha$ and $T R \beta$ genes both in muscle and liver tissues, provided that $T R \alpha$ expression quantities were considerably higher than $T R \beta$, although the differences were found statistically insignificant $(P>0.05)$. Results of this study revealed an endocrine interaction between deltamethrinbased formulation and TH homeostasis corroborating previous researches that approved deltamethrin as an endocrine disrupting compound.
\end{abstract}

Keywords: fish, bioassay, synthetic pyrethroid, gene expression, $m R N A$

\section{Introduction}

A great deal of chemical substances dumped to the aquatic environment disrupt endocrine homeostasis in organisms by interfering with developmental processes and endocrine systems (Mortensen et al., 2006). Endocrine disrupting chemicals (EDCs) are endocrine active compounds causing specific effects on endocrine systems at several levels without relevant toxic actions (Kloas, 2002; Kloas and Lutz, 2006). In respect to the European Union (EU) list of potential EDCs, pyrethroids are candidate substances as compiled in category 1 (Danish EPA, 2016).Pyrethroids are synthetic analogs of pyrethrins, which are toxic components contained in the flowers of Chrysanthemum cinerariaefolium (De Assis et al., 2009). Deltamethrin [(S)- $\alpha$-cyano-3-phenoxybenzyl, (1R)-cis-3-(2,2-)-2,2 dimethycyclopropane carboxylate], the active ingredient of the commercial formulation Metrodesis, is a non-composite synthetic pyrethroid, which is used in control of ectoparasites for animals, as an insecticide in agricultural production and to manufacture long-lasting insecticidal mosquito nets for controlling malaria vectors (Siwicki et al., 2010; Sayeed et al., 2003).

Considering its high efficiency of counteracting the insects, as well as noncumulative characteristic, selective toxicity and rapid photodegradation (Benli et al., 2009), as in other pyrethroids, it has wide acceptability (Erdoğan et al., 2011; Haverinen and Vornanen, 2014; Haverinen and Vornanen, 2016). It is commercially available as 
emulsifiable concentrate for water emulsion and extensively used in Turkey for pest management. In fish, an ectothermic vertebrate, deltamethrin emanated extremely high toxicity (Haya, 1989; Bradbury and Coats, 1989; Viran et al., 2003; Mikata et al., 2011; Srivastav et al., 2010). This is comparatively associated with lower metabolic rate of fish and ineffective metabolic degradation of this neurotoxic agent by fish tissues (Haverinen and Vornanen, 2014; Haverinen and Vornanen, 2016) due to the lack of carboxylesterases (Haya, 1989) that catalyze hydrolysis of pyrethroids in the liver (Srivastav et al., 1997). Furthermore, the lipophilic structure of deltamethrin entails the high rate of gill absorption which is an another remarkable factor to elucidating the high sensivity of fish to toxicity (Viran et al., 2003; Mikata et al., 2011; Srivastav et al., 2010).Some critical toxic effects of deltamethrin on fish can be varied with respect to species, age of the fish and duration of the exposure and elaborated as cardiotoxicity (Haverinen and Vornanen, 2014), disturbance of the calcium and phosphate homeostasis (Srivastav et al., 1997), changes in liver, gill and gut histopathology (Cengiz and Unlu, 2006), inducing hyperglycemia (Aziz et al., 2009) and significant alterations in blood chemistry and kidney function (Aziz et al., 2009; Kumar et al., 1999). It is also noteworthy that, deltamethrin acts as a oxidative stressor and causes inhibition of activity in various proteins including antioxidant enzymes (Erdoğan et al., 2011) and inducing the expression of HSP70 (Ceyhun et al., 2010b), CYP 1A, MT-A, $M T-B$ (Erdoğan et al., 2011) and reducing $I G F$ s and $G H$ in rainbow trout (Aksakal et al., 2010). Although some studies has been done on the impacts of deltamethrin-based formulations (Decis) on avians and fish (Marques et al., 2014; Bhaskar et al., 2016), nevertheless, there are limited researches related to the endocrine disrupting potential of this chemical on fish (Brander et al., 2016; Tu et al., 2016) when we consider the extensive use of this commercial formulations for the pest management.

The thyroid hormones (THs; $\mathrm{T}_{4}, \mathrm{~T}_{3}$ ) regulate a wide range of cellular functions, including growth, development, differentation, metabolism and maintenance of homeostasis, in almost every tissue of teleost (Brent, 1996; Marchand et al., 2001; Filby and Tyler, 2007). Regulation of gene expression by TH is mediated by nuclear thyroid hormone receptors (TRs) (Wu and Koenig, 2000) which has two forms (TR $\alpha$ and TR $\beta$ ) encoded by distinct genes (Filby and Tyler, 2007). As presented in Kloas and Lutz (2006), thyroid system of fish is affected direct or indirectly via accumulation via exposure or the food chain by endocrine disrupters and a detailed understanding of hypothalamus-pituarity-thyroid (HPT) axis regulation in teleosts is necessary to whole evaluation of thyroid-disrupting impacts of environmental compounds.

Therefore, the present paper aims to reveal the endocrine disruption potential of commercially available insecticide of deltamethrin (Metrodesis) in a well-known teleost, Oncorhynchus mykiss, centering upon the TH mechanism regarding to TRs as a response to sublethal exposure.

\section{Materials and Methods}

\section{Insecticide}

The commercial formulation tested, Metrodesis, is manufactured by Özbaşkent Kimya, Ankara, Turkey. It is an emulsifiable concentrate formulation containing $25 \mathrm{~g}$ deltamethrin/L in light aromatic solvent naptha (petroleum>25\%). 


\section{Experimental design}

Rainbow trout (Oncorhynchus mykiss) (mixed sex) with a mean body weight of $83.36 \pm 7.73 \mathrm{~g}$ (Mean \pm S.D., $n=252)$ were obtained from Cifteler Sakaryabasi Aquaculture and Research Station of Ankara University in Eskişehir, Turkey where the experiments were conducted. Prior to experiments for acclimatization, fish were kept in 200 L tank, aerated consistently, for two weeks and fed daily with commercial trout feed (45\% crude protein) ad libitum. Fish were deprived of feed for $48 \mathrm{~h}$ before and during the experiment. To eliminate the fish faeces and excess feed, the water in the tanks were changed (10\%) by siphoning and replaced with fresh water in the acclimatization period. All tanks were shielded with netting material to prevent fish from escape and minimize stress during the trials. The maintenance of the animals and the experiments were performed under approved protocols in accordance with the principles of Ankara University Animal Ethics Committee (Date/No: 16.02.2011/2011105-384). In exposure system, providing triplicates per each concentration (fish per tank; preliminary, main and control: 4 / sublethal and control: 10), dosing solutions of deltamethrin were prepared from Metrodesis and the calculation of dosing solutions was done according to the active ingredient of insecticide. The dosing volumes never exceeded $0.2 \mathrm{ml}$.

\section{Water analysis}

The water quality was evaluated (APHA, 1995) and the measurements of physicochemical parameters of water during the preliminary (range finding), main $\left(\mathrm{LC}_{50}\right)$ and sublethal toxicity tests were presented in Table 1.

Table 1. The physicochemical parameters of water during the preliminary $(P)$, main $(M)$ and sublethal (S) toxicity tests (Mean values \pm S.D.) $(n=3)$.

\begin{tabular}{lccc}
\hline Parameters & $\mathbf{P}$ & $\mathbf{M}$ & $\mathbf{S}$ \\
\hline Dissolved oxygen $(\mathrm{mg} / \mathrm{L})$ & $6.36 \pm 0.01$ & $6.45 \pm 0.06$ & $6.48 \pm 0.03$ \\
$\mathrm{pH}$ & $6.93 \pm 0.05$ & $7.21 \pm 0.10$ & $7.26 \pm 0.08$ \\
Temperature $\left({ }^{\circ} \mathrm{C}\right)$ & $19.60 \pm 0.80$ & $20.10 \pm 0.60$ & $20.00 \pm 0.40$ \\
Electrical conductivity $(\mu \mathrm{S} / \mathrm{cm})$ & $309.30 \pm 15.60$ & $416.30 \pm 9.70$ & $415.70 \pm 5.20$ \\
Alkalinity $(\mathrm{mg} / \mathrm{L} \mathrm{CaCO} 3)$ & $40.00 \pm 0.00$ & $40.00 \pm 0.00$ & $40.00 \pm 0.00$ \\
Hardness $(\mathrm{mg} / \mathrm{L} \mathrm{CaCO} 3)$ & $56.80 \pm 2.00$ & $46.00 \pm 5.30$ & $28.00 \pm 8.50$ \\
$\mathrm{NH}_{3}-\mathrm{N}(\mathrm{mg} / \mathrm{L})$ & $0.65 \pm 0.12$ & $0.98 \pm 0.02$ & $0.83 \pm 0.04$ \\
$\mathrm{NO}_{2}-\mathrm{N}(\mathrm{mg} / \mathrm{L})$ & $0.01 \pm 0.00$ & $0.01 \pm 0.00$ & $0.01 \pm 0.00$ \\
$\mathrm{NO}_{3}-\mathrm{N}(\mathrm{mg} / \mathrm{L})$ & $1.42 \pm 0.26$ & $1.36 \pm 0.20$ & $1.29 \pm 0.30$ \\
\hline
\end{tabular}

\section{Acute toxicity $\left(\mathrm{LC}_{50}-\right.$ Median lethal concentration)}

Acute toxicity tests were carried out in compliance with the standardized methods (OECD, 1992) at two stages in unrenewable static experimental conditions for $96 \mathrm{~h}$ with a total number of 192 fish. In stage I, a range finding (preliminary) test was performed 
to determine the concentrations of the main acute test by using wide ranges (Schäperclaus, 1979) as follows, $0.5,1,5,10,50,100,200,300 \mu \mathrm{g} / \mathrm{L}$ of dosing concentrations. In stage II, with regard to the preliminary test results, six concentrations $(4,8,10,16,32$ and $50 \mu \mathrm{g} / \mathrm{L})$ that comprised $0 \%$ and $100 \%$ death were chosen as the main acute toxicity concentrations. Meanwhile, control groups (non-exposure) were maintained for both preliminary and main exposure tests in triplicates.In the course of exposure tests, dead individuals were removed immediately from the tanks and behavioral changes and mortalities were monitored closely and noted down every $24 \mathrm{~h}$. The Probit regression, a dose-response, analysis was used to compute the median lethal concentration $\left(\mathrm{LC}_{50}\right)$ of deltamethrin, with confidence limit of $95 \%$, for $96 \mathrm{~h}$ exposure (Unsal, 1996).

\section{Sublethal toxicity}

For the assessment of sublethal effects of Metrodesis ( $25 \mathrm{~g}$ deltamethrin/L), 1/4 of 96 $\mathrm{h} \mathrm{LC}_{50}$ value as computed in acute toxicity test, was considered and exposed as a sublethal concentration. The sublethal exposure tests were conducted in triplicates for both treatment and control groups with total number of 60 fish in static system likewise in acute toxicity tests.

\section{Sampling of fish tissues}

At the end of the sublethal exposure of deltamethrin, the tissue samples (liver and white muscle) of rainbow trout were collected from all individiuals of both exposure and control groups. The dissection of liver and muscle tissues was performed on crushed ice and the samples were flash-frozen in liquid nitrogen and preserved at $-80^{\circ} \mathrm{C}$ for further procedures.

\section{RNA isolation and reverse transcription into cDNA}

Total RNA was isolated from the frozen tissues using High Pure RNA Tissue Kit (Roche Diagnostics) according to the manufacturer's instructions. The purity of isolated RNA was quantified by spectrophotometric absorbance $\left(\mathrm{A}_{260} / \mathrm{A}_{280}\right.$ ratio) using a Nanodrop ND-1000 spectrophotometer (Thermo Fisher Scientific, Schwerte, Germany) and the integrity of RNA samples was verified by agarose gel electrophoresis on agarose gel that comprised ethidium bromide (EB). The complementary DNA (cDNA) was synthesized by reverse transcribing from total RNA using the transcriptor first strand cDNA Synthesis Kit (Roche Diagnostics) following the protocol of the manufacturer. Random hexamer primer was chosen in reverse transcribing of cDNA due to the use of $18 S \mathrm{rRNA}$ as a housekeeping gene. The cDNAs were stored at $-20^{\circ} \mathrm{C}$ until used for real-time PCR (RT-PCR).Gene-specific primer pairs and probes were provided from Universal ProbeLibrary (UPL) system (Roche Diagnostics) which constituted a web-based software (ProbeFinder software). UPL probes are hydrolysis probes substituted with Locked Nucleic Acids (LNA) and they are labeled at the $5^{\prime}$ end with FAM (Fluorescein amidite) and at the $3^{\prime}$ end with a dark quencher dye. The sequences of primer pairs and probes were presented in Table 2. 
Table 2.Primer and probe sequences of reference (housekeeping) and target genes of 18S, TR $\alpha, T R \beta$ respectively, in rainbow trout (Oncorhynchus mykiss).

\begin{tabular}{llll}
\hline Gene & Primer/Probe & Sequence & $\begin{array}{c}\text { Gene } \\
\text { Bank } \\
\text { Accession No. }\end{array}$ \\
\hline $18 S$ & Forward primer & ATGGTCTAACATCTTATAAGCGGCTT & AF308735.1 \\
& Reverse primer & GCGCAGAGAAGTTGACTGG & \\
& UPL ${ }^{*}(\# 1$ 18, cat.no. 04693523001) & CACTGGGA & \\
$T R \alpha$ & Forward primer & GAGAAGAGGAAGAAGGAGGAGAT & AF302245.1 \\
& Reverse primer & GAACTTGCGTTTCTGTTTCCA & \\
& UPL (\#24, cat.no. 04686985001) & CAGCTCCC & \\
FR $\beta$ & Forward primer & GAGGCCCACATGTCAACTAAC & AF302246.1 \\
& Reverse primer & TGGTTCCTTCACCCCCACT & \\
& UPL (\#37, cat.no. 04687957001) & TGCCCTGG & \\
\hline
\end{tabular}

*UPL; Universal ProbeLibrary Probe

\section{RT-PCR procedure}

The amplification was performed with a LightCycler 480 RT-PCR system (Roche, Switzerland) using LightCycler 480 Probes Master Kit (Roche Diagnostics). The thermal cycling conditions consisted of an initial pre-incubation for $10 \mathrm{~min}$ at $95^{\circ} \mathrm{C}$, followed by 45 cycles of denaturation of the target DNA at $95^{\circ} \mathrm{C}$ for amplification of the target DNA with for $10 \mathrm{~s}$, primer annealing at $60^{\circ} \mathrm{C}$ for $30 \mathrm{~s}$, extension at $72^{\circ} \mathrm{C}$ for 1 $\mathrm{s}$ and 1 cycle of cooling for $30 \mathrm{~s}$ at $40^{\circ} \mathrm{C}$.A standart curve was constituted for target and housekeeping gene seperately and efficiency of each reaction (1.8-2.0) was determined. PCR samples were run in duplicates for standarts, samples and negative controls. Negative control samples (nuclease-free water instead of cDNA) were used in each run to test the target specifity of the cDNA amplification.

\section{Data normalization}

The housekeeping gene $18 S$ was used as an endogenous standart and expressions of target genes of $T R \alpha$ and $T R \beta$ were normalized to the corresponding level of $18 S$ mRNA relatively to the untreated control by using comparative $\mathrm{Ct}\left(2^{-\Delta \Delta C_{T}}\right.$ ) method (Livak and Schmittgen, 2001).

\section{Statistics}

All data were expressed here as means \pm standart error of the mean (SEM) unless indicated otherwise. A total of ten fish were used from exposure and control groups and two technical replicates per fish and treatment were made. Paired Samples T-test, a confidence level of 95\%, was applied using statistical software IBM SPSS Statistics 23.0 to determine the presence of significant differences among the groups. 


\section{Results}

\section{Median lethal concentration $\left(L_{50}\right)$}

The calculated 96-h acute $\mathrm{LC}_{50}$ value of Metrodesis ( $25 \mathrm{~g}$ deltamethrin/L) in a static bioassay system for rainbow trout was $16.582 \mu \mathrm{g} / \mathrm{L}\left(\chi^{2}=0.500\right)$ with $95 \%$ confidence limits of 13.525-22.156 using Probit regression analysis. The sublethal concentration was $4.15 \mu \mathrm{g} / \mathrm{L}$ and determined as $1 / 4$ of $96-\mathrm{h} \mathrm{LC}_{50}$ value. The behavioral responses of the individuals during the acute exposure were observed and recorded every $24-\mathrm{h}$. In the highest concentration $(50 \mu \mathrm{g} / \mathrm{L})$, within an hour, test fish were demonstrated reactions including movements as trembling and fasciculation, poising at upright, tendency to swim to the water surface and gulping for air. At all concentrations, excessive mucus secretion was detected and below $50 \mu \mathrm{g} / \mathrm{L}$, fish were quite motionless and mostly gathered at the edge of the tanks with high respiration frequency. Control test groups were comparatively calm and no significant behavioral changes were monitored.

\section{Expression of TRs in white muscle and liver}

The relative expression levels of $T R \alpha$ and $T R \beta$ genes in white muscle and liver tissue of rainbow trout after exposed to sublethal treatment of deltamethrin $(4.15 \mu \mathrm{g} / \mathrm{L})$ were presented in Table 3. Sublethal exposure of deltamethrin did not emerge a statistical difference $(P>0.05)$ in expression of TR $\alpha$ gene between white muscle and liver tissue, however a slight but insignificant up-regulation was observed in liver tissue compare to white muscle. Similarly, no significant mRNA alteration $(P>0.05)$ was detected for TR $\beta$ of white muscle and liver tissue with respect to the toxic treatment. Unlikely from $T R \alpha$ expression pattern, the white muscle tissue was slightly up-regulated for $T R \beta$ gene, though the difference was nominal. However, when we compare the results in a genespecific manner, for $T R \alpha$ gene, an apparent increase of mRNA in the white muscle, which was about 5 fold, was recorded compare to liver tissue, whereas the liver tissue was 6 fold higher than white muscle. In general, the relative expression quantity of TR $\alpha$ gene was found considerably high in comparison to $T R \beta$ for both white muscle and liver tissue due to the 96-h sublethal exposure of deltamethrin. Nonetheless, no statistical differences were noted $(P>0.05)$ according to Paired samples T-Test, although a remarkable effect was observed corresponding to deltamethrin treatment

Table 3.mRNA expression levels of TR $\alpha$ and TR $\beta$ genes in white muscle and liver tissue of rainbow trout that are expressed relative to control values and normalized to $18 S$ with their respective standard errors in response to $4.15 \mu \mathrm{g} / \mathrm{L}$ of deltamethrin.

\begin{tabular}{ccc}
\hline \multirow{2}{*}{ Gene } & \multicolumn{2}{c}{ Fish Tissue } \\
\cline { 2 - 3 } & White muscle & Liver \\
\hline $\boldsymbol{T R} \boldsymbol{\alpha}$ & $3.036 \pm 1.57^{\text {N.S.* }}$ & $3.129 \pm 1.63$ \\
$\boldsymbol{T R} \boldsymbol{\beta}$ & $0.679 \pm 0.16$ & $0.578 \pm 0.19$ \\
\hline
\end{tabular}

*N.S. (Non-significant); Means (Means \pm S.E.M) $(n=5)$ in the same row and column were found in-significant according to Paired Samples T-test $(P>0.05)$. 


\section{Discussion}

Deltamethrin, a synthetic pyrethyroid, is well-known with its rapid knock down action in insects, low persistence in the environment and low mammalian toxicity (Erdoğan et al., 2011). Despite these aspects and wide spread on a global scale, it has become the most controversial environmental compound due to the potential of high toxicity to aquatic organisms notably to fish. Here, the $96 \mathrm{~h}$ acute $\mathrm{LC}_{50}$ value of commercial formulation of deltamethrin, Metrodesis, in rainbow trout was found 16.582 $\mu \mathrm{g} / \mathrm{L}$. In quite a few research have been reported the $\mathrm{LC}_{50}$ of deltamethrin in a variety of fish and their findings, which are consistent with the present study result, revealed the potential of high toxicity of this substance to fish. Ural and Sağlam (2005) stated that incremental concentrations of deltamethrin exposure, duration of $96 \mathrm{~h}$, led to increase the number of death fry fish in rainbow trout, that the estimated $\mathrm{LC}_{50}$ value was 0.6961 $\mu \mathrm{g} / \mathrm{L}$. Similar observations were notified for common carp by Koprucu and Aydin (2004) after $48 \mathrm{~h}$ exposure and the $\mathrm{LC}_{50}$ values were 0.213 and $0.074 \mu \mathrm{g} / \mathrm{L}$ for embryos and larvae, respectively. The toxicity takes effect in a time, dose, specie and the size manner as so in young mirror carp that the $\mathrm{LC}_{50}$ values were found 9.41, 4.47, 2.37 and $1.65 \mu \mathrm{g} / \mathrm{L}$ in the time of $24,48,72$ and $96 \mathrm{~h}$ of exposure in a static bioassay system (Calta and Ural, 2004). In the same work, the toxicity studies for deltamethrin compiled in a table for Poecilia reticulata $(5.13 \mu \mathrm{g} / \mathrm{L}$ for $48 \mathrm{~h})$, Clarias gariepinus $(40.01 \mu \mathrm{g} / \mathrm{L}$ for $96 \mathrm{~h})$, Esox lucius $(23.0 \mu \mathrm{g} / \mathrm{L}$ for $96 \mathrm{~h})$ and Ctenopharyngodon idella $(91.0 \mu \mathrm{g} / \mathrm{L}$ for 96 h). The other $\mathrm{LC}_{50}$ studies in Oreochromis niloticus as reported by Golow and Godzi (1994) and Boateng et al. (2006) resulted with values of 14.5 and $15.47 \mu \mathrm{g} / \mathrm{L}$, these results were comparable with the present data even in the case of different species. The exposure with deltamethrin revealed behavioral changes in the treatment groups, in congruent of the present study, Ural and Saglam (2005) also monitored some responses in $O$. mykiss as loss of equilibrium, hanging vertically, erratic swimming, air gulping from the water surface, staying motionless and color darkening in the concentrations of $1,2,4,6,8,10,12,25$ and $50 \mu \mathrm{g} / \mathrm{L}$, and no changes in the control group. Similar changes were detected in P.reticulata(Viran et al., 2003), Cyprinus carpio(Koprucu and Aydin, 2004) and O. niloticus(Golow and Godzi, 1994).

The previous reports of deltamethrin toxification posed the critical influences on fish physiology. The hypocalcemia, observed in Heteropneustes fossilis, a freshwater catfish, after the exposure of deltamethrin for $96 \mathrm{~h}$ with a $\mathrm{LC}_{50}$ value of $1.86 \mu \mathrm{g} / \mathrm{L}$, could be the response of impairment of electrolyte influx at the gill (Srivastav et al., 1997). In the long-term exposure of deltamethrin $(0.37 \mu \mathrm{g} / \mathrm{L}$ for 28 days $)$, prolactin cells of $H$. fossilis exhibited hyperactivity which is inferred by degranulation and accreted nuclear volume to cope with the hypocalcemia (Srivastav et al., 2010). Further, Srivastav et al. (1997) also stated that the exposure elicited hypophosphatemia due to the redistribution of electrolytes between the intracellular or the extracellular compartments of renal function. In furtherance, it has been represented that the erythropoiesis have been accelerated to avoid from anaemic state tending to increase the production of erythrocytes in a research by Kumar et al. (1999), they pointed to the alterations in morphological and functional structure of renal tubules and liver cells, which the $\mathrm{LC}_{50}$ value is recorded as $0.52 \mu \mathrm{g} / \mathrm{L}$ for the same specie, H. fossilis, as indicated above. Excess of melano macrophage centers, congestion, odema and lymphocytic infiltrations were observed for liver tissue, whereas hemorrhages in several sites of kidney associated with renal tubule damage in Clarias lazera were noticed after acute exposure of $0.5 \mu \mathrm{g} / \mathrm{L}$ for one week (Aziz et al., 2009). Moreover, gill activity and 
heart $\mathrm{NA}^{+} \mathrm{K}^{+}$-ATPase were inhibited by deltamethrin exposure whereas the liver total CYP450 and EROD activity were induced in Ancistrus multispinis as reported by De Assis et al. (2009). Besides its neurotoxic characteristic, Haverinen and Vornanen $(2014 ; 2016)$ asserted that deltamethrin is also cardiotoxic to fish and this response could be interpreted with the high affinity of fish $\mathrm{Na}^{+}$channels to deltamethrin as in other pyrethroids. The immunosuppressive and oxidative stress inducing potencial of deltamethrin were evidenced in various researches including different fish species and should not be underestimated. The dose of 2 and $4 \mu \mathrm{g} / \mathrm{L}$ of deltamethrin conduced cellmediated and humoral-mediated immunosupression in rainbow trout which left the fish vulnerable to viral and bacterial disease (Siwicki et al., 2010). Due to the primary sites of deltamethrin absorption, gills are the most susceptible tissues to exposure and it is not puzzling that the reducing levels of oxidative stress indicators in terms of catalase, GST and GPx were obtained from the gills of Channa punctatus after $0.75 \mu \mathrm{g} / \mathrm{L}$ of deltamethrin treatment (Sayeed et al., 2003) and this coincided to a series of researches in rainbow trout as performed by Ceyhun et al. $(2010 \mathrm{a}, \mathrm{b})$.

THs participates in several metabolic functions in terms of development, growth and metamorphosis in fish (Nelson and Habibi, 2009) and presented their activity by binding to $T R$ s (genomic pathway) or through a rapid non-genomic signaling pathway (Manchado et al., 2009), nonetheless the action mechanism for fish is not fully understood.TRs are members of a large superfamily of nuclear receptors (NR), along with steroid hormones, retinoids and vitamin D (Mortensen et al., 2006). TRs have a core role in the genomic regulation of THs (Power et al., 2001), particularly they appear in the early development and metamorphosis in fish (Manchado et al., 2009; Filby et al., 2006) and serve different functions and demonstrate tissue-specific and developmental state-specific expression (Chen et al., 2002; Tu et al., 2016). EDCs, which deltamethrin is regarded as acting a member of this extensive compound group (Mnif et al., 2011)induce to changes, particularly inhibitory ones, in formation and synthesis of THs, affect their bioavailability by binding deiodinases which is responsible for activation or inactivation of THs in peripheral tissues (Kloas and Lutz, 2006). In the present study, $T R \alpha$ was up-regulated in comparison to $T R \beta$ for both liver and white muscle tissue after sublethal exposure of deltamethrin-based formulation, despite the differences were found statistically insignificant. The increased mRNA levels of TR $\alpha$ was totally associated with $T R$ s subtypes (TR $\alpha$ and $T R \beta$ ) as mentioned by Filby et al. (2006). Tu et al. (2016)reported that bifenthrin and $\lambda$-cyhalothrin, two synthetic pyrethroid, exposure conduced to remarkably higher mRNA levels of TRagene in zebrafish which is consistent with this study results. Considering these results, exposure of pyrethroids comparatively can be responsible for the disruption of motor activity associated with the alterations of TH levels (Brander et al., 2016) and concurrent increase in calcium values (Kaul et al., 1996).

\section{Conclusion}

Overall results of this study, suggest that sublethal exposure of deltamethrin-based insecticide Metrodesis, led to alteration in expression of $T R$ s subtypes, specifically $T R \alpha$, independent from tissue-manner, emanating wider potential impacts on the physiological function of fish. Considering the extensive use of this chemical and its high toxicity to aquatic organisms, the specification of risk assessment, particulary endpoints and molecular mechanisms regarding toxicity is a dictate of environmental 
sustainability. Further studies are needed to understand the dose-response relationship between deltamethrin and deltamethrin based formulations and endocrine disruption centering upon non-target organisms as fish.

Acknowledgements. This research was funded by The Scientific and Technological Research Council of Turkey (TUBITAK) with a project number of "1110066" and the author was grateful to Mahmut Selvi, Yeliz Kaşko Arıcı, Emre Tepedelen, Bala Gür, Tülin Otbiçer Acar, Mevlüt Kındır and Ünal Arslan for their precious assistance.

\section{REFERENCES}

[1] Aksakal, E., Ceyhun, S. B., Erdogan, O., Ekinci, D. (2010): Acute and long-term genotoxicity of deltamethrin to insulin-like growth factors and growth hormone in rainbow trout. - Comparative Biochemistry and Physiology Part C 152: 451-455.

[2] APHA (1995). Standart Methods for the Examination of Water and Wastewater. $19^{\text {th }}$. Edition, Washington, USA.

[3] Aziz, M. A., Hegazi, H. M., Abd El-Khalik, M. M., Taha, M. M. A. (2009): Effect of deltamethrin on liver and kidney function of Clarias lazera fish. - Kafrelsheikh Veterinary Medicine Journal $3^{\text {rd }}$ Scientific Congress, 10-12 May 2009, 206-232.

[4] Benli, A. C. K., Selvi, M., Sepici-Dincel, A., Sarıkaya, R., Yıldırım, M. Z., Ozkul, A., Erkoc, F. (2009): Acute toxicity of beta-cypermethrin on Nile tilapia (Oreochromis niloticus L.) fingerlings. - Journal of Environmental Protection and Ecology 10(1): 104109.

[5] Bhaskar, N., Shahani, L., Bhatnagar, P.(2016): Toxicological implications of a commercial formulation of deltamethrin (Decis $\left.{ }^{\circledR}\right)$ in developing chick embryo. - Human and Ecological Risk Assessment 22(2): 369-378.

[6] Boateng, J. O., Nunoo, F. K. E., Dankwa, H. R., Ocran, M. H.(2006): Acute toxic effects of deltamethrin on tilapia, Oreochromis niloticus (Linnaeus, 1758). - West African Journal of AppliedEcology9: 1-5.

[7] Bradbury, S. P., Coats, J. R.(1989): Comparative toxicology of the pyrethroid insecticides. - Reviews of Environmental Contamination and Toxicology108: 133-177.

[8] Brander, S. M., Gabler, M. K., Fowler, N. L., Connon, R. E., Schlenk, D.(2016): Pyrethroid pesticides as endocrine disruptors: Molecular mechanisms in vertebrates with focus on fishes. - Environmental Science and Technology50: 8977-8992.

[9] Brent, G. A.(1996): Thyroid hormones (T4, T3). - In: Melmed, S. (ed.) Endocrinology: Basic and Clinical Principles. Totowa: Humana Press.

[10] Calta, M., Ural, M. S.(2004): Acute toxicity of the synthetic pyrethroid deltamethrin to young mirror carp, Cyprinus carpio.- Fresenius Environmental Bulletin13: 1179-1183.

[11] Cengiz, E. I., Unlu, E.(2006): Sublethal effects of commercial deltamethrin on the structure of the gill, liver and gut tissues of mosquitofish Gambusia affinis: a microscopic study. - Environmental Toxicology and Pharmacology21: 246-253.

[12] Ceyhun, S. B., Senturk, M., Erdogan, O., Kufrevioglu, O. I.(2010a): In vitro and in vivo effects of some pesticides on carbonic anhydrase enzyme from rainbow trout (Oncorhynchus mykiss) gills. - Pesticide Biochemistry and Physiology97: 177-181.

[13] Ceyhun, S. B., Senturk, M., Ekinci, D., Erdogan, O., Ciltas, A., Kocaman, E. M.(2010b): Deltamethrin attenuates antioxidant defense system and induces the expression of heat shock protein 70 in rainbow trout. - Comparative Biochemistry and Physiology Part C 152: 215-223.

[14] Chen, H., Xiao, J., Hu, G., Zhou, J., Xiao, H., Wang, X.(2002): Estrogenicity of organophosphourous and pyrethroid pesticides. - Journal of Toxicology and Environmental Health Part A 65: 1419-1435. 
[15] Danish EPA (2016). The EU list of potential endocrine disruptors. http://eng.mst.dk/topics/chemicals/endocrine-disruptors/the-eu-list-of-potential endocrine-disruptors/. Accessed: 16.11.2016.

[16] De Assis, H. C. D. S., Nicareta, L., Salvo, L. M., Klemz, C., Truppel, J. H., Calegari, R.(2009): Biochemical biomarkers of exposure to deltamethrin in freshwater fishAncistrus multispinis.- Brazilian Archives of Biology and Technology 52(6): 14011407.

[17] Erdoğan, O., Ceyhun, S. B., Ekinci, D., Aksakal, E.(2011): Impact of deltamethrin exposure on mRNA expression levels of metallothionein A, B and cytochrome P450 1A in rainbow trout muscles. - Gene 484: 13-17.

[18] Filby, A. L., Thorpe, K. L., Tyler, C. R.(2006): Multiple molecular effect pathways of an environmental oestrogen in fish. - Journal of MolecularEndocrinology 37:121-134.

[19] Filby, A. L., Tyler, C. R.(2007): Cloning and characterization of cDNAs for hormones and/or receptors of growth hormone, insulin-like growth factor-I, thyroid hormone, and corticosteroid and the gender-, tissue-, and developmental-specific expression of their mRNA transcripts in fathead minnow (Pimephales promelas). - General and Comparative Endocrinology 150: 151-163.

[20] Golow, A. A., Godzi, T. A.(1994): Acute toxicity of deltamethrin and dieldrin to Oreochromis niloticus (L.). - Bulletin of Environmental Contamination and Toxicology 52(3): 351-354.

[21] Haya, K.(1989): Toxicity of pyrethroid insecticides to fish. - Environmental Toxicology and Chemistry8: 381-391.

[22] Haverinen, J., Vornanen, M.(2014): Effects of deltamethrin on excitability and contractility of the rainbow trout (Oncorhynchus mykiss) heart. - Comparative Biochemistry and Physiology Part C 159: 1-9.

[23] Haverinen, J., Vornanen, M.(2016): Deltamethrin is toxic to the fish (crucian carp, Carassius carassius) heart. - Pesticide Biochemistry and Physiology129: 36-42.

[24] Kaul, P. P., Rastogi, A., Hans, R. K., Seth, T. D., Seth, P. K., Srimal, R. C.(1996): Fenvalerate-induced alterations in circulatory thyroid hormones and calcium stores in rat brain. - Toxicology Letters 89(1): 29-33.

[25] Kloas, W.(2002): Amphibians as model for the study of endocrine disruptors. International Review of Cytology216: 1-57.

[26] Kloas, W., Lutz, I.(2006): Amphibians as model to study endocrine disrupters. - Journal of Chromatography A 1130: 16-27.

[27] Koprucu, K., Aydın, R.(2004): The toxic effects of pyrethroid deltamethrin on the common carp (Cyprinus carpio L.) embryos and larvae. - Pesticide Biochemistry and Physiology80: 47-53.

[28] Kumar, S., Lata, S. Lata, Gopal, K.(1999): Deltamethrin induced physiological changes in freshwater catfish Heteropneustes fossilis. - Bulletin of Environmental Contamination and Toxicology62: 254-258.

[29] Livak, K. J., Schmittgen, T. D.(2001): Analysis of relative gene expression data using real-time quantitative PCR and the $2^{-\triangle \Delta C_{T}}$ method. - Methods 25: 402-408.

[30] Manchado, M., Infante, C., Rebordinos, L., Cañavate, J. P.(2009): Molecular characterization, gene expression and transcriptional regulation of thyroid hormone receptors in Senegalese sole. - General Comparative Endocrinology160: 139-147.

[31] Marchand, O., Safi, R., Escriva, H., Rompaey, E. V., Prunet, P., Laudet, V.(2001): Molecular cloning and characterization of thyroid hormone receptors in teleost fish. Journal of Molecular Endocrinology 26: 51-65.

[32] Marques, A., Custódio, M., Guilherme, S., Gaivão, I., Santos, M. A., Pacheco, M.(2014): Assessment of chromosomal damage induced by a deltamethrin-based insecticide in fish (Anguilla anguilla L.) - A follow-up study upon exposure and post-exposure periods. Pesticide Biochemistry and Physiology 113: 40-46. 
[33] Mikata, K., Isobe, N., Kaneko, H.(2011): Biotransformation and enzymatic reactions of synthetic pyrethroids in mammals. - Topics in Current Chemistry 314: 113-136.

[34] Mnif, W., Hassaine, A., Bonaziz, A., Bartegi, A., Thomas, O., Roig, B.(2011): Effect of endocrine disrupter pesticides: A review. - International Journal of Environmental Research and Public Health 8(6): 2265-2303.

[35] Mortensen, A. S., Kortner, T. M., Arukwe, A.(2006): Thyroid hormone-dependent gene expression as a biomarker of short-term 1,1-dichloro-2,2-bis(p-chlorophenyl)ethylene (DDE) exposure in European common frog (Rana temporaria) tadpoles. - Biomarkers 11(6): 524-537.

[36] Nelson, E. R., Habibi, H. R.(2009): Thyroid receptor subtypes: Structure and function infish. - General Comparative Endocrinology 161: 90-96.

[37] OECD (1992). Guideline for the Testing of Chemicals: Fish, Acute Toxicity Test, No: 203.

[38] Power, D. M., Llewellyn, L., Faustino, M., Nowell, M. A., Bjornsson, B. T., Einarsdottir, I. E., Canario, A. V., Sweeney, G. E.(2001): Thyroid hormones in growth and development of fish. - Comparative Biochemistry and Physiology Part C 130(4): 447459.

[39] Sayeed, I., Parvez, S., Pandey, S., Bin-Hafeez, B., Haque, R., Raisuddin, S.(2003): Oxidative stress biomarkers of exposure to deltamethrin in freshwater fish, Channa punctatus Bloch. - Ecotoxicology and Environmental Safety56: 295-301.

[40] Schäperclaus, W. (1979): Fischkankheiten. - Akademie Verlag, Berlin.

[41] Srivastav, A. K.,Srivastava, S. K., Srivastav, S. K.(1997): Impact of deltamethrin on serum calcium and inorganic phosphate of freshwater catfish, Heteropneustes fossilis.Bulletin of Environmental Contamination and Toxicology59: 841-846.

[42] Srivastav, A. K., Srivastava, S. K., Mishra, D., Srivastav, S. K.(2010): Deltamethrininduced alterations in serum calcium and prolactin cells of a freshwater teleost, Heteropneustesfossilis.- Toxicological and Environmental Chemistry 92(10): 1857-1864.

[43] Siwicki, A. K., Terech-Majewska, E., Grudniewska, J., Malaczewska, J., Kazun, K., Lepa, A.(2010): Influence of deltamethrin on nonspecific cellular and humoral defence mechanisms in rainbow trout (Oncorhynchus mykiss). -Environmental Toxicology and Chemistry 29(3): 489-491.

[44] Tu, W., Xu, C., Lu, B., Lin, C., Wu, Y., Liu, W.(2016): Acute exposure to synthetic pyrethroids causes bioconcentration and disruption of the hypothalamus-pituitary-thyroid axis in zebrafish embryos. - Science of the Total Environment542: 876-885.

[45] Unsal, M.(1996): Kirlilik Deneyleri-Yöntemler ve Sonuçların Değerlendirilmesi. - ODTÜ Deniz Bilimleri Enstitüsü, Mersin, Turkey.

[46] Ural, M., Saglam, S. N.(2005): A study on the acute toxicity of pyrethroid deltamethrin on the fry rainbow trout (Oncorhynchus mykiss Walbaum, 1792). - Pesticide Biochemistry and Physiology83: 124-131.

[47] Viran, R., Erkoç,F., Polat,H., Koçak, O.(2003): Investigation of acute toxicity of deltamethrin on guppies (Poecilia reticulata). - Ecotoxicology and Environmental Safety55: 82-85.

[48] Wu, Y., Koenig, R. J.(2000): Gene regulation by thyroid hormone. - Trends in Endocrinology and Metabolism 11(6): 207-211. 